\title{
LABORATORY CONTROL FOR PRODUCTION OF SAFE PLANT PRODUCTS
}

\author{
Kovshun L. O., Tereshchenko N. Yu.
}

\section{INTRODUCTION}

Ensuring sustainable development of both crop production and processing of plant products is possible only with constant monitoring of the process of cultivation and processing in accordance with established safety standards. Development and improvement of methods for extraction of xenobiotics of different groups (pesticides, polycyclic aromatic hydrocarbons) with subsequent chromatographic analysis of their content in crop and food products is a topical and timely issue to ensure sustainable crop production development.

\section{Measuring the content of residual amounts of pesticides in tomatoes}

There are more than 150 varieties and hybrids of tomatoes zoned and grown in Ukraine, which differ in productivity, ripening dates, type, shape, fruit color and resistance to various diseases. Almost two hundred plant protection products (PPP) are used in cultivation of this culture ${ }^{1}$, to minimize the impact of destructive factors and give the fruits of tomatoes consumer qualities, preserving the beneficial properties for human organism. As a rule, after the application of PPP on the culture for a certain period of time, the active substances of PPP accumulate in the composition of different parts of the plant and protect the plant from the negative factor. Residual amounts of pesticides PPP provide plant protection, however, the consumption of fruit with food during this period, is accompanied with the entry into the consumer's body of various dangerous xenobiotics ${ }^{2}$. To protect the health of consumers in the

1 Коломієць Ю.В., Григорюк І.П., Буценко Л.М. Ефективність впливу фунгіцидів на збудників бактеріальних хвороб томатів. Вісник аграрної науки. 2015. № 10. C. 21-24.

2 Антоненко А.М. Пестициди як чинники ризику розвитку хвороб щитоподібної залози: гігієнічна регламентація та обгрунтування критеріїв гігієнічного моніторингу : автореф. дис. ... докт. мед. наук : 14.02.01. Київ, 2019. 35 c. 
developed world, the content of pesticide residues in crop and processed products is standardized and carefully controlled. In Ukraine, the norms of pesticide residues are set by state sanitary rules and regulations ${ }^{3}$. The State Sanitary Rules and Regulations (DSanPiN) 8.8.1.2.3.4-000-2001 also specifies the method of product testing (MPT) used for the implementation of appropriate laboratory control. Also laboratory control of crop products today is carried out by accredited laboratories of various forms of ownership according to the tested and certified MPT, specified in the field of accreditation of the laboratory. Proper laboratory control of crop production in the factory allows the manufacturer to identify and control critical points of production, to produce safe and high quality products. It should be noted, that export batches of products usually require the manufacturer to control a much wider list of pesticide residues, in comparison with the established DSanPiN of Ukraine 8.8.1.2.3.4-000-2001. Each country-importer of Ukrainian products has its own list of xenobiotics and carries out appropriate laboratory control on its territory. At the same time, in Ukraine there is a need to conduct appropriate research to ensure the protection of domestic producers and ensure their competitiveness in foreign markets.

As the state standardized methods of laboratory control are not updated so quickly, and the state safety requirements are harmonized only in time according to foreign requirements, manufacturers-exporters carry out certification of production in corresponding foreign laboratories, or in accredited research divisions of leading scientific institutions of the country ${ }^{4}$. The study of the vast majority of names of residual amounts of xenobiotics, including pesticides, is carried out using chromatographic methods with different types of detectors. For example, the authors of $[5]^{5}$. applied the method of gas mass spectrometry (GC / MS / MS) to the analysis of residual amounts of pesticides in extracts of

3 ДСанПіН 8.8.1.2.3.4-000-2001. Допустимі дози, концентрації, кількості та рівні вмісту пестицидів у сільськогосподарській сировині, харчових продуктах, повітрі робочої зони, атмосферному повітрі, воді водоймищ, грунті. Постанова Головного державного санітарного лікаря України від 20.09.2001 р. № 137.

${ }^{4}$ Ушкалов В.О., Данчук В.В., Самкова О.П., Баранов Ю.С. та ін. Біологічна безпека: результати моніторингу агроресурсів, продукції АПК та харчових продуктів за 2014-2016 роки. Ветеринарна медицина: Міжвідомчий тематичний науковий збірник. 2017. № 103. С. 88-92.

${ }^{5}$ Melo, A., Cunha, S.C., Mansilha, C., Aguiar, A., Pinho, O., \& Ferreira, I.M. (2012). Monitoring pesticide residues in greenhouse tomato by combining acetonitrile-based extraction with dispersive liquid-liquid microextraction followed by gas-chromatography-mass spectrometry. Food chemistry, 135(3), 1071-1077. 
samples of crop products. The working range of measurement of residual pesticides in the sample was from $0.01 \mathrm{mg} / \mathrm{kg}$ to $0.2 \mathrm{mg} / \mathrm{kg}$, the minimum percentage of xenobiotic extraction is not less than $70 \%$, and the maximum is not more than $116 \%$. The value of the relative standard deviation of the average value of the measured amount of pesticide content depends on its chemical group and the structure of the molecule, ranging from $3 \%$ to $19 \%$, except for chlorothalonil (23\%). The data obtained in ${ }^{6}$ suggest that the authors of the work proposed satisfactory conditions for extraction and measurement of pesticides in the plant extract. In ${ }^{7}$, a new method was proposed for the quantitative determination of pesticide residues, which differed in the stage of purification of pesticide extract from coextractive compounds of the matrix using gel permeation chromatography. The use of gel permeation chromatography made it possible to obtain pesticide solutions purified from matrix compounds and to determine their content by gas chromatography (GC / MS) and liquid chromatography (HPLC / MS / MS). It was found that the detection limit of pesticides depends on the chemical structure of the analyte and is in the range from $0.2 \mathrm{mg} / \mathrm{kg}$ to $6.0 \mathrm{mg} / \mathrm{kg}$, the correlation coefficient of the linear dependence of the zone of working concentrations was $r \geq 0.98$. The authors performed validation studies of the proposed analytical method to determine the residual amounts of pesticides in the green mass and samples of vegetables and fruits. The results of the certification of the method showed that the percentage of pesticide extraction is in the range from 80 to $120 \%$. However, the authors, examining the results of testing the proposed methodology in three different laboratories found that to ensure $100 \%$ detection and identification of target pesticides, it is necessary to coordinate the work of the measuring equipment.

The aim of the research is to test the method of laboratory control of pesticide residues in tomato fruits, tomato paste and tomato juice.

The work was performed using solvents and qualification reagents "for chromatography" and "pure for analysis": acetonitrile, methanol, deionized water, formic acid, acetic acid, trifluoroacetic acid, hydrochloric acid, sulfuric acid, sodium hydroxide, sulfate sodium chloride, calcium chloride, sodium citrate. Sorbents $\mathrm{Al} 2 \mathrm{O} 3$ and $\mathrm{nSiO} 2$,

\footnotetext{
${ }^{6}$ Albero, B., Sánchez-Brunete, C., \& Tadeo, J.L. (2003). Determination of endosulfan isomers and endosulfan sulfate in tomato juice by matrix solid-phase dispersion and gas chromatography. Journal of chromatography A, 1007(1-2), 137-143.

${ }^{7}$ Cortés, J.M., Vázquez, A., Santa-María, G., Blanch, G.P., \& Villén, J. (2009). Pesticide residue analysis by RPLC-GC in lycopene and other carotenoids obtained from tomatoes by supercritical fluid extraction. Food chemistry, 113(1), 280-284.
} 
activated carbon of OU-A brand (DSTU 4453-74), SPE columns (ChromSpher Pi, Varian ${ }^{\mathrm{TM}}$ ), cartridges filled with mixtures of primary and secondary amines, Supel amines were used to clean plant extracts from co-active substances. filled with graphitized coal produced by Supelco. Sampling was carried out in accordance with the relevant regulations. Samples of crop products were used in the work: fruits of tomatoes of different varieties, tomato paste and tomato juice. Parallel laboratory samples were formed, of which three samples, in one study, were subjected to artificial enrichment with target xenobiotics or markers of different groups of xenobiotics. Homogenization of the samples was performed by grinding in a beaker laboratory mill-homogenizer LZM-1, at different temperatures (from $+4^{\circ} \mathrm{C}$ to $+25^{\circ} \mathrm{C}$ ). To buffer the solution of the layer of homogenized sample and at the stage of purification of the plant extract used chemical compounds of qualification "pure for analysis": magnesium sulfate, sodium chloride, sodium citrate dihydrate, potassium citrate, calcium chloride, alumina. The extraction was carried out by maceration in plastic tubes made of polytetrafluoroethylene, in flasks made of dark glass and plastic flasks made of polymethylpentene, protected by opaque casings. Intensification of mass transfer during the extraction of analytes occurred by varying the ratio of raw material-extractant, under the action of temperature, stirring, ultrasonic waves with a frequency of $37 \mathrm{kHz}$ (generated by the installation of Advantage Lab). The separation of the phases of the extraction system was performed using a Thermo Scientific centrifuge, for 10 minutes at constant speed at a speed of 4000 to $7000 \mathrm{rpm}$, at a temperature in the centrifuge chamber from $4{ }^{\circ} \mathrm{C}$ to $20{ }^{\circ} \mathrm{C}$. The obtained plant extract isolated after centrifugation from the plant material was subjected to purification from coextractive substances by methods of dispersion solid-phase extraction using organic solvents and sorbents: mixtures of primary and secondary amines, graphitized coal or by liquidliquid crosslinking. Concentration of the purified xenobiotic extract was performed using a rotary evaporator from IKA. Analysis of the content of xenobiotics in the solutions obtained from the extracts was performed according to the list of analytes by high-performance chromatography with mass-selective detector using chromatograph Dionex Summit MSD3200Q TRAP, gas mass spectrometry using chromatograph GC / MS A.01.10.3ies / Agile, by high performance liquid chromatography with fluorescent and diode matrix detectors (HPLC / FLD and HPLC / DBP / FLD) using Ultimate 3000 chromatographs from Dionex.

The method of measuring the content of residual amounts of pesticides in samples of crop products consists of three main stages: 
obtaining plant extract, obtaining working solutions, instrumental control of xenobiotics. At the first stage from the homogenized sample of crop production there is an extraction from the sample of available pesticides to the composition of the plant extract. To do this, a system of organic solvent - aqueous-saline solution - a homogenized sample. Not only target pesticides but also coextractive substances are extracted into the organic layer.

Table 1

List of target pesticides, lower limit and error of quantitative measurement of the analyte $(N=3, n=10, P=0.95)$

\begin{tabular}{|c|c|c|c|c|c|}
\hline Compound & $\begin{array}{c}\text { Lower } \\
\text { limit, } \\
\mathbf{m g} / \mathbf{~ k g}\end{array}$ & $\begin{array}{c}\text { Mistake, } \\
\mathbf{\%}\end{array}$ & Compound & $\begin{array}{c}\text { Lower } \\
\text { limit, } \\
\mathbf{M g} / \mathbf{k g}\end{array}$ & $\begin{array}{c}\text { Mistake, } \\
\mathbf{\%}\end{array}$ \\
\hline azoxystrobin & 0.01 & 9.8 & pyraclostrobin & 0.01 & 9.0 \\
\hline deltamethrin & 0.01 & 9.5 & rimsulfuron, & 0.01 & 10.0 \\
\hline dimethoate & 0.01 & 9.1 & thiamethoxam & 0.01 & 10.0 \\
\hline dimetomorph & 0.01 & 9.5 & tebuconazole & 0.01 & 9.3 \\
\hline difenoconazole & 0.01 & 9.0 & thiacloprid & 0.01 & 9.7 \\
\hline methomyl & 0.01 & 10.0 & terbuthylazine & 0.01 & 9.1 \\
\hline mankoceb & 0.01 & 9.6 & famoxadone & 0.01 & 9.3 \\
\hline metalaxyl-m & 0.01 & 9.2 & fludioxonil & 0.01 & 9.7 \\
\hline $\begin{array}{c}\text { lambda- } \\
\text { cyhalothrin }\end{array}$ & 0.01 & 9.6 & $\begin{array}{c}\text { fluazifop- } \\
\text { p-butyl }\end{array}$ & 0.01 & 9.9 \\
\hline metribuzin & 0.01 & 10.0 & $\begin{array}{c}\text { chylazofop- } \\
\text { p-ethyl }\end{array}$ & 0.01 & 9.8 \\
\hline s-metolachlor & 0.01 & 9.7 & chlorpyrifos & 0.01 & 9.5 \\
\hline
\end{tabular}

The results of analytical signals, spectra of analytes were processed using calibration dependencies, database library of the program Cromeleon 6.0 and library of mass spectra NIST 0.5 .

As can be seen from Table 1, 22 chemical compounds are extracted to the plant extract, the chemical composition of coextractive substances has not been studied, because coextractive compounds are isolated from plant extract using solid-phase and liquid-liquid extraction methods (TFE and PPE). Plant extract of pesticides is investigated by chromatographic methods in accordance with the conditions of the certified method developed for quantitative measurement of a certain group of analytes in crop products. As can be seen from table 1, the lower limit of determination of pesticide residues of different chemical groups is at the level of $0.01 \mathrm{mg} / \mathrm{kg}$, the measurement error does not exceed $10 \%$. 
Comparing the value of the lower limit of determination of the analyte and the rate of its content in the fruits of tomatoes (DSanPiN 8.8.1.2.3.4000-2001, 2001) and products of their processing, it was found that this method allows you to control the above safety indicators. The upper limit of determination of pesticide residues listed in table 1 is $1.0 \mathrm{mg} / \mathrm{kg}$, the measurement error does not exceed $4 \%$.

To confirm the possibility of determining the pesticide content in the presence of other xenobiotics by this method, as well as in the case of incomplete purification of plant extract from coextractive substances, the analysis of plant extracts that did not contain analytes (3 parallels of blank samples), model systems and artificially enriched pesticides of tomato fruit samples with different variations in the chemical composition of analytes and coextractive compounds.

Table 2

The range of the amount of pesticides and metrological characteristics of the set content

\begin{tabular}{|c|c|c|c|c|c|}
\hline \multirow{3}{*}{ Compound } & \multirow{2}{*}{$\begin{array}{l}\text { Importe } \\
\mathbf{d}, \mathbf{~ m g} / \mathbf{k g}\end{array}$} & \multicolumn{4}{|c|}{$\begin{array}{c}\text { Metrological characteristics } \\
\text { set value of the content }\end{array}$} \\
\cline { 3 - 6 } & 0.01 & $\mathbf{X}_{\mathbf{C P}}$ & $\mathbf{C V , \%}$ & Removal, \% & Mistake, \% \\
\hline \multirow{3}{*}{ Azoxystrobin } & 0.01 & 3.8 & $90-110$ & 10 \\
\cline { 2 - 6 } & 0.05 & 0.04 & 2.7 & $80-100$ & 10 \\
\cline { 2 - 6 } & 1.0 & 0.97 & 3.0 & $95-101$ & 3.1 \\
\hline \multirow{3}{*}{ Dimetomorph } & 0.01 & 0.01 & 4.2 & $92-108$ & 8 \\
\cline { 2 - 6 } & 0.05 & 0.05 & 3.1 & $90-110$ & 10 \\
\cline { 2 - 6 } & 1.0 & 0.96 & 3.5 & $92-100$ & 4 \\
\hline \multirow{3}{*}{ Chlorpyrifos } & 0.01 & 0.01 & 4.0 & $90-100$ & 10 \\
\cline { 2 - 6 } & 0.05 & 0.05 & 3.9 & $90-100$ & 10 \\
\cline { 2 - 6 } & 1.0 & 0.90 & 4.6 & $84-98$ & 6 \\
\cline { 2 - 6 } & 0.01 & 0.01 & 3.2 & $90-100$ & 10 \\
\cline { 2 - 6 } & 0.05 & 0.05 & 3.9 & $90-100$ & 10 \\
\hline
\end{tabular}

As can be seen from Table 2, the obtained average values $\left(\mathrm{X}_{\mathrm{av}}\right)$, as expected, coincide, within the error, with the levels of xenobiotics included in the sample. During testing, it was investigated and confirmed that the working range of measurement of pesticide residues in the sample is from $0.01 \mathrm{mg} / \mathrm{kg}$ to $1.0 \mathrm{mg} / \mathrm{kg}$, the minimum percentage of xenobiotic extraction is not less than $80 \%$ and the maximum not more than $110 \%$, the measurement error does not exceed $10 \%$ and decreases in the range of analyte concentrations from $0.5 \mathrm{mg} / \mathrm{kg}$ to $1.0 \mathrm{mg} / \mathrm{kg}$. The value of the coefficient of variation of the measured amount of pesticide 
content varies in the range from $2 \%$ to $5 \%$. The data shown in table 2 were obtained by chromatographic analysis. Detection of peaks of analytes of the lower limit of quantitative measurement $(0.01 \mathrm{mg} / \mathrm{kg})$ was performed at a noise / signal ratio of 1 noise: 6 signal. The instrumental methods of gas and liquid chromatography mass spectrometry used are selective methods. When obtaining chromatograms in the method of liquid chromatography, selective conditions for the collection of ions of the corresponding analyte were applied. In the method of gas mass spectrometry in the processing of chromatograms was used the function of purification of spectra, the principle of mass fragmentation - the selection of a set of masses obtained by ionization by electron impact $(70 \mathrm{eV})$, masses characteristic of the target analyte. In combination with the retention time recorded in accordance with the retention time of the analytical standard, this facilitates the processing of the results of chromatographic analysis.

53 samples of tomato fruits, 5 samples of tomato paste and 10 samples of tomato juice were analyzed. According to the results of chromatographic control on the chromatograms of 47 samples, no xenobiotics corresponding to pesticidal compounds were detected (by retention time and peak mass spectra). The vast majority of samples did not contain pesticides. However, one sample of tomato fruit and five samples of tomato paste containing target pesticides were found in the study. The established results of the amount of pesticides in tomatoes and tomato paste were compared with their permissible content allowed by DSanPiN of Ukraine 8.8.1.2.3.4-000-2001. Tomato paste contains from one to four pesticides in an amount that did not exceed the established hygienic standards. Five pesticides were detected in tomatoes with registration code (RC) 12, no other pesticide chemical compounds were detected.

Table 3

The list of pesticides and the results of control of their residual amounts in the sample of fruits of tomatoes r.k. 12

\begin{tabular}{|c|c|c|c|}
\hline Name of indicators & Definitely, mg / kg & Norms & Norms $^{* *}$ \\
\hline Azoxystrobin & 0.01 & not normalized & 0.3 \\
\hline Deltamethrin & 0.01 & 0.3 & 0.3 \\
\hline Dimetomorph & $<0.01$ & not normalized & 0.1 \\
\hline Metalaxyl-M & 0.01 & 0.04 & 0.2 \\
\hline Pyraclostrobin & $<0.01$ & 0.3 & 0.3 \\
\hline
\end{tabular}

* State sanitary rules and norms DSanPiN 8.8.1.2.3.4-000-2001

** PESTICIDES EU-MRLs Regulation (EC) No 396/2005, Tomatoes 
In each of the samples of tomato paste and in the sample of tomato fruits RC 12, shown in table 3, revealed dimetomorph. Dimetomorph the active substance of plant protection products with fungicidal action, allowed to protect vegetable crops of potatoes, tomatoes, cucumbers, onions and grapes from a complex of diseases. According to the recommendations for the use of spraying the plant with the drug is carried out until the first signs of the disease, and treated throughout the growing season with an interval of 7 to 14 days. Dimetomorph alone is not used, this pesticide is part of three-component and two-component drugs with mancoceb, pyraclostrobin, metalaxyl or ametoctradine. Mancozeb is unstable in the environment, quickly hydrolyzed (from several hours to three days) in acidic and alkaline environment, residual amounts of this compound in the samples can be detected only in the first days after treatment of the plant. Residual amounts of pyraclostrobin and metalaxyl-M found in the products indicate that these pesticides are not only stable in the environment, but also do not decompose under pasteurization. Analyzing the residual amounts of active substances of the detected drugs, we can assume that the drugs were used according to the instructions and did not exceed the recommended application rates. Detected pesticide residues are less than the maximum allowable level.

\section{Isolation of polycyclic aromatic hydrocarbons from sunflower oil}

Today, modern laboratory research methods require the use of a large number of expensive consumables and reagents imported to Ukraine. During previous studies of xenobiotics in samples of plant raw materials and oils, as well as studying the physicochemical properties of xenobiotics, possible ways to save and optimize the use of certain consumables were predicted ${ }^{8,9,10}$, including through various methods of intensification of extraction processes. in the system of plant material-

8 Nesterova L.O., Hrybova N.Y., Khyzhan O.I., Ushkalov V.O. (2018). Development of controls method for the isomers of polycyclic aromatic hydrocarbons in vegetable oils. Scientific Journal of National University of Life and Environmental Sciences of Ukraine. Series: Agronomy, 286, 312-320.

${ }^{9}$ Hrybova N.Yu. (2018). Xenobiotics of PAHs group is extracted from sunflower seeds. Scientific Journal of National University of Life and Environmental Sciences of Ukraine. Series: Agronomy, 294, 209-218.

${ }^{10}$ Grybova N.Y. et al (2018). Determination of Polycyclic Carbohydrates in Atmospheric Water by the Method of Chromatography. Journal of Water Chemistry and Technology, 40 (5), 297-301. 
extractant ${ }^{11,12}$. In addition to establishing conditions for intensification of extraction processes and economical use of consumables and solvents, a significant interest in terms of rationalization and greening of methods for testing crop products for polycyclic aromatic hydrocarbons (PAH), is a liquid of vegetable origin - oil used as an extractant for some drugs ${ }^{13}$. However, the presence of xenobiotics with carcinogenic activity in the composition of sunflower oil - polycyclic aromatic hydrocarbons limits its use as an extractant ${ }^{14}$. The known industrial process of the most complete purification of sunflower oil from xenobiotics allows to obtain refined oil brand "D", in which still remain xenobiotics at the level of $1 \mu \mathrm{g} / \mathrm{kg}$. The use of brand D oil for the manufacture of drugs creates the preconditions for the content of trace amounts of xenobiotics of the PAH group in the composition of the drug.

Industrial purification of oil from xenobiotics is carried out using various sorbents ${ }^{15,16,17}$, among which there is no data on the use of inexpensive, available and known enterosorbent - activated carbon used to bind xenobiotics and toxins in the gastrointestinal tract ${ }^{18,19}$.

It is known that the chemical composition of unrefined oil or crude oil is characterized by the presence of xenobiotics PAH, free fatty acids,

${ }^{11}$ Gribova N.Yu., Filippenko T.A., Nikolaevskii A.N., Khizhan E.I., Bobyleva O.V. (2008) Effects of ultrasound on the extraction of antioxidants from bearberry (Arctostaphylos adans) leaves. Pharmaceutical Chemistry Journal, 42 (10), 593-595.

${ }^{12}$ Грибова Н.Ю. Влияние условий экстракции на антиоксидантные свойства извлеченных фитофенолов. Методы и объекты химического анализа. 2012. Вып. 7, № 4. С. 202-206.

13 Бисага С.I., Олійник С.В., Вишневська Л.І., Герасимова I.В. та ін. Хроматографічні дослідження олійних екстрактів 3 трави селери пахучої та пастернаку посівного. Сучасні досягнення фармацевтичної технологї $i$ біотехнології : збірник наук. пр. Харків, 2017. С. 52-54.

14 Toxicological Review of Benzo[a]pyrene (2017). Review of EPA's Draft Assessment. U.S. Environmental Protection Agency. Washington: EPA. 97 p.

${ }^{15}$ Huang, Y., Zhou, Q., \& Xie, G. (2011). Development of micro-solid phase extraction with titanate nanotube array modified by cetyltrimethylammonium bromide for sensitive determination of polycyclic aromatic hydrocarbons from environmental water samples. Journal of hazardous materials, 193, 82-89.

16 Спосіб видалення поліциклічних ароматичних вуглеводнів. Патент 104865 Україна. Опублікований 25.03.2014, Бюл. № 6, 2014 рік.

17 Спосіб визначення вмісту поліциклічних ароматичних та ароматичних вуглеводнів у продуктах, що містять харчові олії та жири. Патент 82364 Україна. Опублікований 10.04.2008, Бюл. № 7, 2008 рік.

18 Косцевич Н.М. Визначення антимікробної та адсорбційної активності вугілля, збагаченого фітоекстрактами. Проблеми екологічної біотехнології. 2015. № 1 .

19 Khrokalo, L.A., Pylypenko, T.M., \& Verves, K.Y. (2018). Additional properties of pharmaceutical preparations: active coal and white coal. Біологічні системи: теорія та інновації. 2018. № 287. С. 1219-135. 
phosphatides, natural waxes, tocopherol, natural vitamins, aromatic substances and trace amounts of water ${ }^{20}$. In appearance, crude oil, due to the high content of waxes and phosphatides, is cloudy and opaque. In the process of hydration and neutralization, deodorization, bleaching and freezing, the oil removes the remnants of concomitant substances, as well as eliminates existing impurities, the oil becomes transparent and odorless. However, xenobiotics such as PAH are not completely removed from the crude oil, residual amounts of PAH are allowed in refined sunflower oil. Order of the Ministry of Health of Ukraine № 368 of 13.05.2013 "On approval of State hygienic rules and regulations" established the permissible content of benzo (a) pyrene not more than $2 \mu \mathrm{g} / \mathrm{kg}$ and $10 \mu \mathrm{g} / \mathrm{kg}$ - the maximum total content of three PAH (benzo (a) anthracene, benzo (a) pyrene, benzo (b) fluoranthene), but for dietary and baby food oils, the residual content of any of the above substances, or the total content of a group of PAH may not exceed $1 \mu \mathrm{g} /$ $\mathrm{kg}$. Analyzing the above norms, it can be assumed that in the refining process bleaching clays (chemical compounds $\mathrm{Al} 2 \mathrm{O} 3$ and $\mathrm{nSiO} 2$ ) and their mixtures with activated carbon can remove all compounds of the $\mathrm{PAH}$ group, but the literature does not specify the conditions of the refining process that lead to the final $(1 \mu \mathrm{g} / \mathrm{kg})$.

Activated carbon has a high porosity, the surface area of one gram of activated carbon can be from 500 to $2200 \mathrm{~m} 2$. The pore radius can be from 0.2 to $200 \mathrm{~nm}$, mainly the adsorption capacity of activated carbon is determined by pores with a size of $0.5-1.6 \mathrm{~nm}$, which are commensurate with the size of the adsorbed molecules ${ }^{21}$. Activated carbon is now widely used for sorption extraction from water of chemical compounds of man-made origin, or as an enterosorbent of toxins ${ }^{22}$. The process of extraction of chemical compounds from different systems on activated carbon occurs due to their absorption and retention by the active centers of the adsorbent. This process is usually explained by the lack of physical interaction between the active centers of the sorbent and the molecules of xenobiotics due to the weak forces of Van der Waals, but,

${ }^{20}$ Осейко М.І. Технологія рослинних олій : підручник. Київ : Варта, 2006. 280 с.

21 ДСТУ ЕN 12915-1:2004, Матеріали для очищення води, призначеної для споживання людиною. Гранульоване активоване вугілля. Частина 1. Чисте гранульоване активоване вугілля (EN 12915-1:2003, IDT)

22 Косцевич Н.М. Визначення антимікробної та адсорбційної активності вугілля, збагаченого фітоекстрактами. Проблеми екологічної біотехнологї. 2015. № 1 .

Khrokalo, L.A., Pylypenko, T.M., \& Verves, K.Y. Additional properties of pharmaceutical preparations: active coal and white coal. Біологічні системи: теорія та інновації. 2018. № 287. С. 1219-1135. 
under certain conditions, chemical reactions can occur on the surface of the sorbent to increase cleaning efficiency due to xenobiotic chemisorption, also possible course of both processes - physical and chemical sorption, which significantly enhances the action of the sorbent and increases the degree of purification of the object from xenobiotics. The most studied application of activated carbon for the removal of xenobiotics of organic nature, such as phenol, benzene, most petroleum products, chlorine and organophosphorus pesticides, polycyclic aromatic hydrocarbons from a solvent of inorganic nature - water. The aim of this work was to study the conditions and establish optimal conditions for the complete separation of crude oil by adsorption on activated carbon of polycyclic aromatic hydrocarbons.

Samples of unrefined and refined sunflower oil were used in the work, the quality indicators of which corresponded to DSTU 4492: 2017. To separate wax and phosphatides from unrefined oil, as well as the sorbent at the stage of studying the adsorption process, was used the method of centrifugation at $4^{\circ} \mathrm{C}$ and the method of vacuum filtration at room temperature using a nylon filter with a cell diameter of $0.46 \mu \mathrm{m}$. The process of extraction of xenobiotics took place by maceration, intensified with action of temperature $\left(25^{\circ} \mathrm{C}\right)$ and constant stirring at a speed of 200 revolutions per minute. Qualification solvents "for chromatography" and "pure for analysis" were used in the work: acetone, methanol, isopropanol, acetonitrile, deionized water, orthophosphoric acid, solutions of analytical PAH standards in acetonitrile and isopropanol. Activated carbon (DSTU EN 12915-1: 2004) was used as a sorbent, which has a developed total porosity, a significant value of the specific absorbing surface (about $1000 \mathrm{~m} 2$ per gram of coal). Work with samples was carried out in accordance with the methods developed in ULYABP APC. The content of xenobiotics in the oil was determined by high performance liquid chromatography with fluorescence detection (HPLC / FLD). The software package Cromeleon 6.0 and MS Exel were used to identify analytical signals of xenobiotics and mathematically calculate the values characterizing the process of $\mathrm{PAH}$ extraction from oil ${ }^{23}$.

23 Nesterova L.O., Hrybova N.Y., Khyzhan O.I., Ushkalov V.O. (2018). Development of controls method for the isomers of polycyclic aromatic hydrocarbons in vegetable oils. Scientific Journal of National University of Life and Environmental Sciences of Ukraine. Series: Agronomy, 286, 312-320. 
Unrefined crude oil was subjected to organoleptic and visual analysis. The crude oil in the physical state is a liquid, a viscous yellow-amber suspension, the suspended phase has a color from light brown to dark brown, the suspended mechanical impurities are evenly distributed throughout the volume of the sample. The suspension is capable of delamination when settling in the tank. A one-liter sample placed in a one-liter measuring cylinder is flaked for 140 to 800 hours, depending on the dispersion, content and volume fraction of the impurities. The use of the method of centrifugation at a temperature of $4^{\circ} \mathrm{C}$ and the method of vacuum filtration at room temperature using a nylon filter with a cell diameter of $0.46 \mu \mathrm{m}$ allow the separation of mechanical impurities from one liter of crude oil in 2.5 hours. The oil purified from mechanical impurities is subject to the study of the initial level of xenobiotics. According to the results of chromatographic analysis, all samples of crude oil contain mixtures of polycyclic aromatic hydrocarbons: benzo (a) anthracene (BaA), benzo (a) pyrene $(\mathrm{BaP})$, benzo (e) pyrene $(\mathrm{BeP})$, benzo (b) fluoranthene $(\mathrm{BBF})$, chrysanthemum (Hr). The established content of xenobiotics in the oil is shown in table 1. From table 4.13 it can be seen that the selected oil samples for study contain different amounts of xenobiotics. Samples №1 and № 2 are characterized by the content of $\mathrm{BaP}$ and the amount of 3PAV at the level of the established norms for edible oils of brand " $D$ " and "P" (Order of the Ministry of Health of Ukraine № 368 of 13.05.2013). Other samples studied in the work and are shown in table 4, are characterized by exceeding the permissible levels of PAH. Oil samples №№ 7-10 are characterized by a content of BaP, which is 5-11 times higher than the permissible content of this xenobiotic in food oils, the analysis of oils with a high content of PAH overloads the chromatographic column and reduces its service life.

Because sample №1 contains the least amount of xenobiotics, it was used to create model systems formed by artificial enrichment of oil with xenobiotics. Oil samples №№ 7-11 were used to test the efficiency of the adsorption PAH extraction conditions under study.

Hrybova N.Yu. (2018). Xenobiotics of PAHs group is extracted from sunflower seeds. Scientific Journal of National University of Life and Environmental Sciences of Ukraine. Series: Agronomy, 294, 209-218. 
Table 4

The results of measuring the PAH content

in samples of crude sunflower oil

\begin{tabular}{|c|c|c|c|c|c|}
\hline \multirow{2}{*}{$\begin{array}{c}\text { Sequence } \\
\text { number of } \\
\text { the sample }\end{array}$} & \multicolumn{5}{|c|}{ The content of xenobiotics, $\boldsymbol{\mu g} / \mathbf{k g}$} \\
\cline { 2 - 6 } & $\mathbf{B a A}$ & BaP & BeP & $\mathbf{B b F}$ & $\begin{array}{c}\text { Chrysant } \\
\text { hemum }\end{array}$ \\
\hline № 1 & $0.5 \pm 0.1$ & $0.9 \pm 0.3$ & $1.2 \pm 0.2$ & $1.0 \pm 0.2$ & $0.9 \pm 0.2$ \\
\hline № 2 & $2.7 \pm 0.4$ & $2.1 \pm 0.4$ & $3.1 \pm 0.6$ & $1.9 \pm 0.3$ & $2.4 \pm 0.5$ \\
\hline № 3 & $5.3 \pm 0.5$ & $4.2 \pm 0.8$ & $4.4 \pm 0.8$ & $3.9 \pm 0.6$ & $3.7 \pm 0.5$ \\
\hline № 4 & $5.9 \pm 0.7$ & $5.0 \pm 0.9$ & $5.4 \pm 0.6$ & $5.9 \pm 0.6$ & $4.1 \pm 0.5$ \\
\hline № 5 & $4.2 \pm 0.5$ & $6.3 \pm 1.1$ & $6.7 \pm 0.9$ & $4.7 \pm 0.4$ & $5.5 \pm 0.6$ \\
\hline № 6 & $7.3 \pm 0.6$ & $8.2 \pm 1.7$ & $9.2 \pm 0.9$ & $7.8 \pm 0.9$ & $8.3 \pm 0.9$ \\
\hline № 7 & $8.7 \pm 1.2$ & $10.6 \pm 2.1$ & $9.8 \pm 1.7$ & $10.0 \pm 1.5$ & $9.7 \pm 1.3$ \\
\hline № 8 & $11.5 \pm 1.1$ & $14.9 \pm 1.4$ & $13.2 \pm 1.5$ & $9.4 \pm 0.9$ & $9.9 \pm 1.2$ \\
\hline № 9 & $12.4 \pm 1.1$ & $17.1 \pm 1.9$ & $14.5 \pm 1.5$ & $16.3 \pm 1.7$ & $17.3 \pm 1.5$ \\
\hline № 10 & $25.1 \pm 2.4$ & $23.2 \pm 1.8$ & $18.3 \pm 1.7$ & $21.2 \pm 2.1$ & $20.8 \pm 2.1$ \\
\hline
\end{tabular}

Sample № 1 was used in the work to create seven model systems in three parallels, which were encrypted and used to study the sorption properties of activated carbon. Analytical standards of individual PAH were introduced into the first five model systems to create a xenobiotic content corresponding to $2.0 \pm 0.2 \mu \mathrm{g} / \mathrm{kg}$. The content of PAH in model systems before studies of the sorption extraction process were investigated by HPLC / FLD. The established content values (c0) characterize the artificially enriched sample (table 5), prepared for a series of tests. As can be seen from table 4.14, the artificially created total xenobiotic content in the experimental series of samples is stable within the error of the test method and averages $5.6 \pm 0.8 \mu \mathrm{g} / \mathrm{kg}$, except for mixtures with the priority xenobiotic benz (a) anthracene, with a total xenobiotic content. within $6.0 \pm 1.2 \mu \mathrm{g} / \mathrm{kg}$.

The list of xenobiotics is individual for each sample in the series and is characterized by the priority content of one of the test compounds. An artificial increase in the concentration of one of the xenobiotics is necessary to study the process of extraction of this compound on activated carbon in different ratios to other xenobiotics. 
Table 5

The results of measuring the content of PAH in an artificially enriched sample of crude sunflower oil № 1

\begin{tabular}{|c|c|c|c|c|c|c|}
\hline \multirow{2}{*}{ Sample code } & \multicolumn{5}{|c|}{ The content of xenobiotics (c0), $\boldsymbol{\mu g}$ / kg } \\
\cline { 2 - 7 } & BaA & BaP & BeP & BbF & $\begin{array}{c}\text { Chrysant } \\
\text { hemum }\end{array}$ & $\begin{array}{c}\text { Amount 5 } \\
\text { PAH }\end{array}$ \\
\hline № 1A 1 & $2.0 \pm 0.4$ & $0.9 \pm 0.3$ & $1.2 \pm 0.2$ & $1.0 \pm 0.2$ & $0.9 \pm 0.2$ & $6.0 \pm 1.1$ \\
\hline № 1 P 1 & $0.5 \pm 0.1$ & $2.0 \pm 0.2$ & $1.2 \pm 0.2$ & $1.0 \pm 0.2$ & $0.9 \pm 0.2$ & $5.6 \pm 0.9$ \\
\hline № 1 E 1 & $0.5 \pm 0.2$ & $0.9 \pm 0.3$ & $2.0 \pm 0.3$ & $1.0 \pm 0.2$ & $0.9 \pm 0.2$ & $5.3 \pm 0.8$ \\
\hline № 1F 1 & $0.5 \pm 0.1$ & $0.9 \pm 0.3$ & $1.2 \pm 0.3$ & $2.0 \pm 0.3$ & $0.9 \pm 0.2$ & $5.5 \pm 0.8$ \\
\hline № 1 Xp 1 & $0.5 \pm 0.2$ & $0.9 \pm 0.3$ & $1.2 \pm 0.3$ & $1.0 \pm 0.2$ & $2.0 \pm 0.2$ & $5.6 \pm 0.8$ \\
\hline № 1A 2 & $2.0 \pm 0.2$ & $0.9 \pm 0.4$ & $1.2 \pm 0.3$ & $1.0 \pm 0.3$ & $0.9 \pm 0.2$ & $6.0 \pm 1.3$ \\
\hline № 1 P 2 & $0.5 \pm 0.1$ & $2.0 \pm 0.2$ & $1.2 \pm 0.2$ & $1.0 \pm 0.1$ & $0.9 \pm 0.1$ & $5.6 \pm 0.6$ \\
\hline № 1 E 2 & $0.5 \pm 0.1$ & $0.9 \pm 0.2$ & $2.0 \pm 0.2$ & $1.0 \pm 0.1$ & $1.0 \pm 0.2$ & $5.4 \pm 0.5$ \\
\hline № 1F 2 & $0.5 \pm 0.1$ & $0.9 \pm 0.1$ & $1.2 \pm 0.2$ & $2.0 \pm 0.2$ & $0.9 \pm 0.1$ & $5.5 \pm 0.6$ \\
\hline № 1 Xp 2 & $0.6 \pm 0.2$ & $0.8 \pm 0.2$ & $1.1 \pm 0.2$ & $0.9 \pm 0.2$ & $2.0 \pm 0.3$ & $5.4 \pm 0.6$ \\
\hline
\end{tabular}

The first parallel of the five model systems was divided into four equal portions weighing $200 \mathrm{~g}$, from which two parallel samples of $100 \mathrm{~g}$ were created. $1 \mathrm{~g}, 3.5 \mathrm{~g}, 6.5 \mathrm{~g}$ and 10 grams of activated carbon were added to each pair of parallel samples. The sorption process took place with constant stirring, at room temperature $25^{\circ} \mathrm{C}$. An aliquot of the oil: activated carbon mixture was selected from the extraction system every 30 minutes, the weight of the aliquot was $1.0 \mathrm{~g}$. The aliquot was separated by filtration: the separated sorbent was returned to the extraction system, and the oil was transferred to the chromatographic stage. The obtained quantitative data were used to calculate the specific adsorption (b) according to formula 1 :

$$
b=\frac{m\left(c_{0}-c_{n}\right)}{\mathrm{k}}
$$

where: $\mathrm{m}$ is the mass of the sample $(100 \mathrm{~g})$, $\mathrm{c}_{0}-\mathrm{PAH}$ content at the beginning of the study, $\mathrm{c}_{\mathrm{n}}-$ the equilibrium concentration of PAH in the oil after a certain period of time,

$\mathrm{k}$ - the mass of activated carbon added to the oil $(5.8,15,25 \mathrm{~g})$.

The equilibrium concentration of PAH in the oil decreased over a period of time, which indicated the course of sorption processes in the system. The degree of extraction of xenobiotics is calculated according to formula 2 : 


$$
\Gamma=\frac{\left(c_{0}-c_{n}\right)}{c_{0}}
$$

where: $\mathrm{c}_{0}-\mathrm{PAH}$ content at the beginning of the study, $\mathrm{c}_{\mathrm{n}}$ is the equilibrium concentration of $\mathrm{PAH}$ in the oil over a period of time.

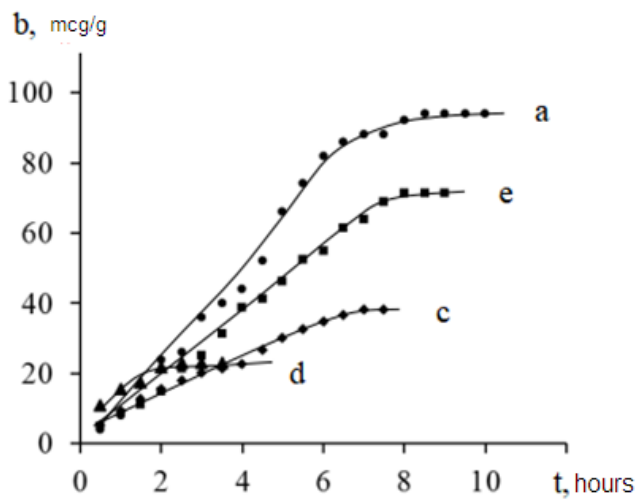

Fig. 1. Dependence of the specific sorption of activated carbon on the duration of the process. Variable component - content of activated carbon:

$$
a-1 g, e-3.5 g, c-6.5 g, d-10 g
$$

Initial total xenobiotic content of $560 \pm 80 \mathrm{ng}$, initial substrate mass $100 \mathrm{~g}, \mathrm{~T} 25^{\circ} \mathrm{C}$, stirring constant $(200 \mathrm{rpm})$.

Figure 1. shows the dependence of the value of the specific sorption of activated carbon calculated according to formula 1 from the duration of the adsorption process, which occurred when adding different amounts of activated carbon.

From Figure 1 we can see that with increasing sorbent mass in the system, the sorption curve reaches the plateau in a shorter period of time, which indicates an increase in the speed of the adsorption process with increasing sorbent mass. The highest rate of PAH extraction from oil is achieved by adding 10 grams of activated carbon, but this system is characterized by the lowest specific sorption, which indicates the low efficiency of the sorbent. The highest value of specific sorption is achieved in the system with a minimum amount of sorbent, namely 1 gram, however, this amount of sorbent allows you to remove only $83 \%$ of the above initial amount of xenobiotics, ie is insufficient for oil purification. 
Almost $99 \%$ of xenobiotics from the studied oil samples were removed with a sorbent weighing $3.5 \mathrm{~g}$ or more. The average duration of the process of extracting PAH from one oil sample with $3.5 \mathrm{~g}$ of activated carbon is 8.5 hours.

Examining the patterns of PAH extraction with approximately the same hydrophobicity parameters ${ }^{24}$, it was found that the lower the molecular weight of the priority xenobiotic, the more time is required for complete PAH extraction from oil (Table 6). As can be seen from table 3 in the first 30 minutes of solid-phase extraction from sample № 1A2 with a priority content of $\mathrm{BaA}(\mathrm{M} \mathrm{BaA}=228 \mathrm{~mol} / \mathrm{g})$ removed $5.3 \%$ of xenobiotics, to completely remove $\mathrm{PAH}$ from this sample requires 510 minutes.

Table 6

Percentage of PAH removal from sample № 1 A 2 and sample № 1P 2 at $\mathrm{T} 25^{\circ} \mathrm{C}$ with $3.5 \mathrm{~g}$ of activated carbon

\begin{tabular}{|c|c|c|c|c|c|c|c|c|c|}
\hline $\mathrm{t}, \mathrm{min}$ & Sample & 30 & 90 & 180 & 360 & 420 & 450 & 480 & 510 \\
\cline { 1 - 9 } w, \% & № 1A 2 & 5.3 & 14.0 & 24.4 & 52.1 & 75.3 & 86.4 & 93.5 & 100 \\
\hline $\mathrm{t}, \mathrm{min}$ & Sample & 30 & 90 & 180 & 360 & 420 & 450 & 480 & 510 \\
\cline { 1 - 8 } $\mathrm{w}, \%$ & № 1П 2 & 8.9 & 19.2 & 36.2 & 77.6 & 89.6 & 98.1 & 100 & 100 \\
\hline
\end{tabular}

For the first 30 minutes of the process, $8.9 \%$ of PAH were removed from the sample № $1 \Pi 2$ with the priority content of $\mathrm{BaP}$ $(\mathrm{M} \mathrm{BaP}=252 \mathrm{~mol} / \mathrm{g})$, which is $3.6 \%$ more than from the sample № $1 \mathrm{~A} 2$ for this period of time. The dynamics of increasing the number of extracted xenobiotics for a sample with a priority content of xenobiotics with a molecular weight of $252 \mathrm{~mol} / \mathrm{g}$, compared with a sample containing a priority xenobiotic with a molecular weight of 228 $\mathrm{mol} / \mathrm{g}$, is maintained throughout the process. The total contact time of the oil-activated carbon phases required for complete removal of PAH from the sample № 1P2 is 480 minutes, which is 30 minutes less than the time spent to remove PAH from the previous sample.

24 Derun, Yu.A. et al. Розрахунки параметрів гідрофобності ізомерів бензопірену для пошуку оптимальних умов вимірювання їх вмісту в атмосферній воді. Хімічні проблеми сьогодення, [S.1.], p. 14, apr. 2018. http://jhps.donnu.edu.ua/article/view/5159 


\section{CONCLUSIONS}

The paper tests the method of measuring the residual amounts of pesticides that remain in the fruit of tomatoes after the use of plant protection products in culture. It is established that the working range of measurement of pesticide residues is from $0.01 \mathrm{mg} / \mathrm{kg}$ to $1.0 \mathrm{mg} / \mathrm{kg}$. The value of the percentage of pesticide extraction from the sample to the plant extract is in the range from $80 \%$ to $110 \%$, the value of the coefficient of variation does not exceed 5\%. The stability of the method was established for 6 months in a series of intra-laboratory studies of reference samples. The method was tested using model systems and 53 samples of tomato fruits, 5 samples of tomato paste, 10 samples of tomato juice. One sample of tomato fruits and five samples of tomato paste with trace amounts of several target pesticides, the content of which did not exceed the established hygienic norms, were found.

Thus, the optimal conditions of the process of adsorption of PAH on activated carbon are achieved in isothermal conditions $\left(25^{\circ} \mathrm{C}\right)$ with constant stirring of the system at a speed of 200 revolutions per minute. The ratio of the mass of the sorbent to the mass of crude oil is variable and depends on the total content of xenobiotics, for every $560 \pm 80 \mathrm{ng}$ xenobiotics of the PAH group must be introduced into the system $1 \mathrm{~g}$ of activated carbon, the average sorption time is $510 \pm 30$ minutes

\section{SUMMARY}

The values characterizing the suitability of the developed and tested method of measuring the content of residual amounts of pesticides in tomato fruits are established. According to the results of chromatographic control on the chromatograms of 47 samples of tomato fruits, no xenobiotics were detected, one sample of tomato fruits and five samples of tomato paste with trace amounts of target pesticides (azoxystrobin, deltamethrin, dimetomorph, metalaxyl-m, perachustro, pyraclo established by regulatory documents in Ukraine and the EU hygienic standards.

A study of the process of separation of polycyclic aromatic hydrocarbons (PAH) from sunflower oil on activated carbon: benzo (a) anthracene, benzo (a) pyrene, benzo (e) pyrene, benzo (b) fluoranthene, chrysanthemum and their mixtures. The PAH content in the samples was determined by the results of chromatographic tests performed by high performance liquid chromatography with a fluorescent detector (HPLC / FLD). Based on the established regularities, the optimal conditions for 
purification of crude sunflower oil from PAH with the help of activated carbon and obtaining a matrix of sunflower oil are proposed.

\section{References}

1. Коломієць Ю.В., Григорюк І.П., Буценко Л.М. Ефективність впливу фунгіцидів на збудників бактеріальних хвороб томатів. Вісник аграрної науки. 2015. № 10. С. 21-24.

2. Антоненко А.М. Пестициди як чинники ризику розвитку хвороб щитоподібної залози: гігієнічна регламентація та обгрунтування критеріїв гігієнічного моніторингу : автореф. дис. ... докт. мед. наук : 14.02.01. Київ, 2019. 35 с.

3. DSanPYN 8.8.1.2.3.4-000-2001. Допустимі дози, концентрації, кількість та рівні вмісту пестицидів у сільськогосподарській сировині, харчових продуктах, повітрі робочої зони, атмосферному повітрі, воді водоймищ, грунті : Постанова Головного державного санітарного лікаря України від 20.09.2001 № 137.

4. Ушкалов В.О., Данчук В.В., Самкова О.П., Баранов Ю.С. та ін. Біологічна безпека: результати моніторингу агроресурсів, продукції АПК та харчових продуктів за 2014-2016 роки. Ветеринарна медицина: Міжвідомчий тематичний науковий збірник. 2017. № 103. С. 88-92.

5. Melo, A., Cunha, S. C., Mansilha, C., Aguiar, A., Pinho, O., \& Ferreira, I. M. (2012). Monitoring pesticide residues in greenhouse tomato by combining acetonitrile-based extraction with dispersive liquid-liquid microextraction followed by gas-chromatography-mass spectrometry. Food chemistry, 135(3), 1071-1077.

6. Albero, B., Sánchez-Brunete, C., \& Tadeo, J.L. (2003). Determination of endosulfan isomers and endosulfan sulfate in tomato juice by matrix solid-phase dispersion and gas chromatography. Journal of chromatography A, 1007(1-2), 137-143.

7. Cortés, J.M., Vázquez, A., Santa-María, G., Blanch, G.P., \& Villén, J. (2009). Pesticide residue analysis by RPLC-GC in lycopene and other carotenoids obtained from tomatoes by supercritical fluid extraction. Food chemistry, 113(1), 280-284.

8. Nesterova L.O., Hrybova N.Y., Khyzhan O.I., Ushkalov V.O. (2018). Development of controls method for the isomers of polycyclic aromatic hydrocarbons in vegetable oils. Scientific Journal of National University of Life and Environmental Sciences of Ukraine. Series: Agronomy, 286, 312-320. 
9. Hrybova N. Yu. (2018). Xenobiotics of PAHs group is extracted from sunflower seeds. Scientific Journal of National University of Life and Environmental Sciences of Ukraine. Series: Agronomy, 294, 209-218.

10.Grybova N. Y. et al (2018). Determination of Polycyclic Carbohydrates in Atmospheric Water by the Method of Chromatography. Journal of Water Chemistry and Technology, 40 (5), 297-301.

11.Gribova N.Yu., Filippenko T.A., Nikolaevskii A.N., Khizhan E.I., Bobyleva O.V. (2008) Effects of ultrasound on the extraction of antioxidants from bearberry (Arctostaphylos adans) leaves. Pharmaceutical Chemistry Journal, 42 (10), 593-595.

12.Грибова Н.Ю. Влияние условий экстракции на антиоксидантные свойства извлеченных фитофенолов. Meтоды $u$ объекты химического анализа. 2012. Вып. 7. № 4. С. 202-206.

13.Бисага С.І., Олійник С.В., Вишневська Л.І., Герасимова І.В. та ін. (2017). Хроматографічні дослідження олійних екстрактів 3 трави селери пахучої та пастернаку посівного. Сучасні досягнення фармачевтичної технології $i$ біотехнології : збірник наук. пр. Харків, 2017. С. 52-54.

14. Toxicological Review of Benzo[a]pyrene (2017). Review of EPA's Draft Assessment. U.S. Environmental Protection Agency. Washington: EPA. 97 p.

15.Huang, Y., Zhou, Q., \& Xie, G. (2011). Development of microsolid phase extraction with titanate nanotube array modified by cetyltrimethylammonium bromide for sensitive determination of polycyclic aromatic hydrocarbons from environmental water samples. Journal of hazardous materials, 193, 82-89.

16.Спосіб видалення поліциклічних ароматичних вуглеводнів. Патент 104865 Україна. Опублікований 25.03.2014, Бюл. № 6, 2014 рік.

17.Спосіб визначення вмісту поліциклічних ароматичних та ароматичних вуглеводнів у продуктах, що містять харчові олії та жири. Патент 82364 Україна. Опублікований 10.04.2008, Бюл. № 7, 2008 рік.

18.Косцевич Н.М. Визначення антимікробної та адсорбційної активності вугілля, збагаченого фітоекстрактами. Проблеми екологічної біотехнології. 2015. № 1.

19. Khrokalo, L.A., Pylypenko, T.M., \& Verves, K.Y. Additional properties of pharmaceutical preparations: active coal and white coal. Біологічні системи: теорія та інноваџіï. 2018. № 287. С. 1219-1135. 
20. Осейко М.І. Технологія рослинних олій: підручник. Київ : Варта, 2006. 280 c.

21.ДСТУ EN 12915-1:2004, Матеріали для очищення води, призначеної для споживання людиною. Гранульоване активоване вугілля. Частина 1. Чисте гранульоване активоване вугілля (EN 12915-1:2003, IDT)

22.Derun, Yu. A. et al. Розрахунки параметрів гідрофобності ізомерів бензопірену для пошуку оптимальних умов вимірювання їх вмісту в атмосферній воді. Хімічні проблеми сьогодення, [S.1.], p. 14, apr. 2018. http://jhps.donnu.edu.ua/article/view/5159

Information about the authors:

Kovshun Lidiia Oleksandrivna,

Doctor Habilitatus in Technical Sciences, Professor, Head of the Department of General, Organic and Physical Chemistry National University of Life and Environmental Sciences of Ukraine 15, Heroyiv Oborony str., Kyiv, 03041, Ukraine

Tereshchenko Nataliia Yuriivna, Candidate of Chemical Sciences, Senior Researcher, Associate Professor at the Department of Medical and General Chemistry Bogomolets National Medical University 34, Peremohy avenue, Kyiv, 03100, Ukraine 